\title{
ECONOMIC AND SOCIAL IMPACTS OF PROMOTING CULTURAL HERITAGE PROTECTION BY THE CZECH RURAL DEVELOPMENT PROGRAMME 2007-2013
}

Jana Kouřilová, Martin Pělucha ${ }^{1}$

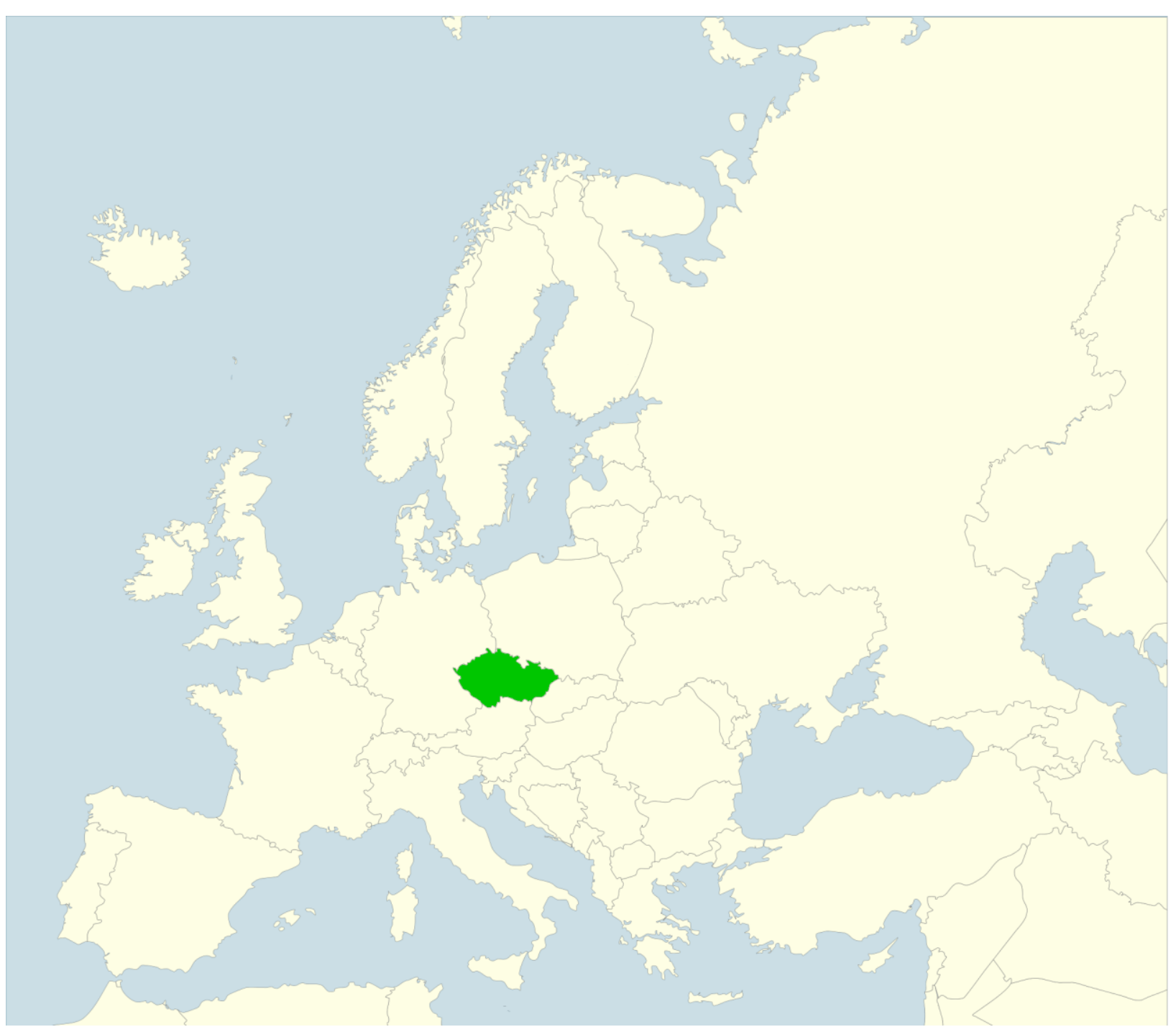

${ }^{1}$ RNDr. Jana Kouřilová, Ph.D., doc. Ing. Martin Pělucha, Ph.D., Department of Regional Studies, Faculty of Economics, University of Economics, Prague, Nám. W. Churchilla 4, 13067 Praha 3, Czechia; e-mails: jana.kourilova@vse.cz, martin.pelucha@vse.cz 


\begin{abstract}
Cultural heritage can play a very important role in local and regional development with economic and social effects. The European Union (EU) outlined a specific measure that is aimed at the protection and development of rural heritage within rural development policy in the programming period of 2007-2013. The main aim of this paper is to assess economic and social impacts of projects supported by EU Rural Policy in the Czech Republic during the period of 2007-2013. The implemented projects were located mainly in peripheral rural areas, both near to borders and in inner peripheries, which means that the measure was geographically well targeted. The results of the measure contribute to the restoration and reconstruction of historical monuments, churches, cemeteries and small sacral monuments which create an environment in rural settlements. This environment is very important for the community life and strengthening local identity. In the field of economic development, the results of this measure demonstrate only limited effects in supported villages.
\end{abstract}

Key words: cultural heritage, rural development, evaluation.

Souhrn: Kulturní dědictví se svými ekonomickým a sociálními dopady sehrává významnou roli v lokálním a regionálním rozvoji. Evropská unie (EU) vytvořila specifický nástroj, který byl zaměřen na ochranu a rozvoj venkovského dědictví v rámci politiky rozvoje venkova $v$ programovém období 2007-2013. Hlavním cílem tohoto príspěvku je posoudit ekonomické a sociální dopady projektů podporovaných politikou EU v oblasti venkova v České republice v období 2007-2013. Realizované projekty se nacházely především v periferních venkovských oblastech, a to jak v blízkosti hranic, tak ve vnitřních periferiích, což znamená, že nástroj byl geograficky dobře zacílen. Výsledky tohoto nástroje přispívají k obnově a rekonstrukci historických památek, kostelů, hřbitovů a malých sakrálních památek, které vytvářejí prostředí ve venkovských osadách. Toto prostředí je velmi důležité pro komunitní život a posilují pocit identifikace obyvatel. Pokud jde o ekonomický rozvoj, vykazují výsledky tohoto nástroje jen omezené dopady v podporovaných obcích.

Klíčová slova: kulturní dědictví, rozvoj venkova, evaluace.

\title{
1. Introduction
}

Rural areas of Central and Eastern Europe faced dramatic changes during the last two centuries - devastating wars, mechanisation of agriculture, industrialisation, urbanisation, suburbanisation (in the second half of the $20^{\text {th }}$ century). These changes contributed to major shifts and transformations of rural areas (Ilbery et al., 1998; Woods, 2011; Ducros, 2014). In the second half of the $20^{\text {th }}$ century, the economic and social development of Central and Eastern Europe's countryside was characterised by a decline in rural population in all countries, except Moldova (Majerová, Pavlíková, Maříková, 2010).

In the late 1980s and 1990s, Central and Eastern Europe were affected by significant political changes, which had a major impact on the further development of these countries. With respect to these initial conditions, countries of Central and Eastern Europe had a similar political and economic development (see more e.g. Sarris, Doucha, Mathijs, 1999; Asztalos Morell, 2014; Sokol, 2001; Chaplin, Gorton, Davidova, 2007; Čapkovičová, 2016). Therefore, this paper has a strong Central European dimension as it is focused on the evaluation of the cultural heritage support in the countryside of the Czech Republic.

The current state of the Czech countryside was influenced by the expulsion of the Germans from the borderlands and a resettlement of this territory after the Second World War. The consequences of these processes can be observed over the long-term up until today. Significant impacts were also associated with the collectivisation and related change in land 
ownership. These changes affected not only the system of agricultural production but also the social climate in the countryside (Pělucha, 2012; Bičík, Jančák, 2005). In this period, the political regime tried to "close the gap between the urban and the rural as an important step towards a communist society" (Pospěch, 2014: 101). The way of life changed in the countryside during the socialist period in the former Czechoslovakia. People moved to towns, due to better job and service opportunities, which led to a gradual deterioration of rural settlements. In accordance with the prevailing ideology, the socialist regime emphasised atheism (Spousta, 2002; Dolista, 2006). Hence, religious monuments also went to ruins, especially in rural areas of the Czech borderland (see e.g. Heřmanová, Chromý et al, 2009).

During the Velvet Revolution (or Gentle Revolution), in the last six weeks of 1989, it caused social and especially economic changes with a significant territorial differentiation in former Czechoslovakia. In rural areas, it was a transformation of agricultural cooperatives and the restitution of property that was confiscated during the period of collectivisation. This process lasted for the whole decade in the 1990s and influenced the agricultural sector and also rural settlements in the Czech Republic (Pělucha, 2012; Bičík, Jančák, 2005; Chromý, Jančák, Marada, Havlíček, 2011; Věžník, Bartošová, 2004). Currently, it can be observed that there are efforts being made by regional and local authorities in looking for ways to restore a local identity, that is very differentiated in the Czech Republic (Šifta, Chromý, 2014; Chromý, Janů, 2003, Vaishar, Zapletalová, 2016). This is reflected in the functional approach to rural areas. This means there is an emphasis on ecological, recreational and other functions according to the concept of multi-functionality in the West (Pospěch, 2014). According to Majerová (2007), the cooperation among local actors is very important for the sustainability of rural areas. This cooperation requires better social communication and organisation. Cultural heritage can be a good basis for these processes (Šmid Hribar, Lozej, 2013). As with other European countries, the Czech Republic is characterised by a large number of historical monuments and buildings. The restoration and maintenance of these monuments is a very expensive process (Pek, 2009). However, a renewal of cultural heritage can significantly contribute to economic and social development at the local level (Hinterstoisser, 2001; OECD, 2005; ESPON, 2013).

The European Council Regulation no. 1698/2005 on support for rural development by the European Agricultural Fund for Rural Development (EAFRD), defined a measure to promote the protection and development of the rural heritage (Article No. 57). The aim of this measure was to improve the quality of life in rural areas and to encourage diversification of economic activities. This measure represented a specific tool of the newly established EU rural policy during period 2007-2013. By this measure, the European Council (EC) confirmed the importance of the cultural heritage, which was also normatively declared in the Resolution of the Council (2007/C287/01) on a European Agenda for Culture.

The Czech Republic, as well as other Central European countries, had a unique opportunity to invest in the protection of the cultural heritage in rural areas during the programming period of 2007-2013. This measure of the EAFRD was also implemented in Poland, Hungary and Austria. However, according to the share of this measure in the aforementioned countries, the importance of the cultural heritage restoration was different. Austria supported their cultural heritage by way of the highest share (33\% of the allocation for Axis III, $2 \%$ of the total allocation of the Rural Development Programme - RDP), followed by the Czech Republic (18\%; $1.5 \%)$ and Hungary $(4.4 \% ; 0.6 \%)$. In Poland, these shares cannot be quantified, because the allocation of the measure there is not mentioned separately. Slovakia, which is the most similar country to the Czech Republic, did not implement this measure. In the Czech Republic, this measure (RDP 2007-2013) was designed as a support system for the architectural and urban development of municipalities with up to 500 inhabitants. Also, supported projects had to comply with the requirements of maintaining and strengthening visual aspects of rural municipalities, as well as increasing the awareness of the identity and social cohesion of local communities.

With respect to the aforementioned broader context of political and economic development in rural areas of Central European countries, it is appropriate to ask some initial research questions. Why is it necessary to solve problems that are associated with cultural heritage in rural areas? Why is it necessary to support the maintenance and restoration of rural cultural heritage? What are the economic and social benefits of this type of support? The main aim of this paper is to 
assess economic and social impacts of cultural heritage protection, which were supported by EU Rural Policy in the Czech Republic during the period of 2007-2013.

The remainder of this paper is organised as follows: the second section presents a theoretical background of cultural heritage importance in local and regional development, the third section briefly describes the methodology used in the analytical process; the fourth section provides details of the research results; the final section provides a synthesis of the key findings together with some policy implications.

\section{Theoretical background}

The European Commission (2014) emphasises normatively that cultural heritage has significant economic and social impacts, not only in relation to tourism, but it can be a part of the cultural and creative industries. This concerns not only urban but also rural areas which can develop traditional and new economic activities based on cultural heritage. This approach is reflected in the policymaking of relevant tools, including the EU rural policy.

Lapuk and Šmid Hribar (2014) pointed out the importance of cultural heritage in business and social issues as a basis for regional and local development. They specifically mentioned economic impacts, especially in relation to tourism, and also social potential for strengthening the identity of localities (i.e. the identification of inhabitants and social integration). This finding is important in the era of globalisation because the rural cultural heritage is a significant witness of the past and has an educational role in terms of understanding the history (PRISMA, 2009). Lempert (2015) confirms the importance of the educational role of cultural heritage for tourism. Moreover, cultural heritage can be perceived as a primary opportunity for tourism development in rural localities with national or international significance (see e.g. an international project THETRIS aimed at the preservation of local churches and sacral monuments in Central European rural areas). Restoration of cultural heritage thus contributes to maintaining the typical rural architectural character of the settlement. Crouch (2006: 362) states that "the consumption aesthetics of the rural in contemporary culture may inform what rurality means to the individual tourist". Nevertheless, Crouch also emphasises that in this ontological view, rural areas represent much more in their "consumption" concept.

Daugstad, Rønningen and Skar (2006) suggest the linkage between agriculture and cultural heritage, traditional manufacturing and products as a way of preserving the cultural heritage in rural areas (see also Mettepenningen et al., 2012). Lee et al. (2005) describe the importance of cultural heritage for local identity and identification of inhabitants with the territory. The importance of social impacts is also confirmed by other authors (Johnson, 2013; Labadi, 2013). In this context, Alumäe et al. (2003) stated that "the cultural heritage and the care of the local values are the main factors contributing to the genesis of the genius loci" (Alumäe et al., 2003, p. 128). Theoretically, this should be ensured by land-use planning regulations (Jablonská, 2005). In the case of the Czech Republic, however, these regulations were not always effective and sufficient due to the frequent willingness of local political representation to meet the different interests of developers, especially in the suburban countryside (Sklenička 2006; Wokoun et al., 2010; Zeman, 2013). The activity and interest of the local community is essential to ensure the protection of local cultural heritage. Wang (2016) refers to this aspect and puts an emphasis on the role of local communities in rural heritage conservation. He distinguishes two different concepts, which are essential for preserving the cultural identity of inhabitants, i.e. "living cultural heritage" and "livedin cultural heritage". These concepts are relevant, particularly for rural communities that are demographically and economically stable in the long term, i.e. they do not face depopulation or suburbanisation.

Courtney, Hill, Roberts (2006) pointed out that rural areas offer not only cultural heritage in terms of various monuments, rural traditions, traditional local products and way of life, but also natural heritage. Shipley, Feick (2009) perceive suburbanisation and the associated urban sprawl as a threat to the natural heritage, and to the traditional character, respectively, of the countryside. Stenseke (2000) emphasises the importance of local social environment for the cultural landscape creation and maintenance. According to Keitsch, Kua and Skjerven (2016), the protection of cultural heritage is related to the sustainable development of the locality. Cultural 
heritage is also an important element influencing local/regional identity that is very crucial in relation to residents' interest in participating in development strategies and their implementation (Šmid Hribar, Bole, Pipan, 2015).

In the body of academic literature, most authors connect economic and social impacts of cultural heritage support. Ray (1998) identified that cultural heritage is a part of the cultural economy.Caftanzoglou, Fittings (1997) emphasised cultural heritage as a source of local human creativity. Bell and Jayne (2010) similarly wrote about the creative countryside. They highlight the need to "understand the conflicts and tensions relating to 'traditional' crafts/arts versus the 'new' emerging creative industries' agendas in rural areas" (Bell, Jayne, 2010: 212).

Other authors emphasise a specific condition of cultural heritage as a source of local development (e.g. Šmid Hribar and Lozej, 2013). Generally, it is necessary to have a coherent strategic concept for the use of particular objects of local cultural heritage. Lysgård (2016) underlines the importance of culture-led strategies for the use of cultural heritage in rural areas; these strategies contribute to collective responsibility for the future of the community and the locality. A concrete idea of the utilisation of cultural heritage is very important because, as Patočka and Heřmanová (2008: 23) stated, "in the Czech Republic, the majority of cultural and technical heritage loses its economic merits in the long-term, i.e. the loss or the gradual disappearance of their utility value". The utilisation of monuments should be a part of a broader strategic plan which enables development options that cultural heritage offers. Kloosterman (2014) also confirms the importance of cultural planning for economic strategies at the local level. In the Czech Republic, these strategies were designed with an emphasis on larger cities rather than on small rural towns or municipalities. These cities were e.g. Ostrava and Pilsen, as they were each nominated as a European Capital of Culture (see e.g. Markova, Tichá, 2011). OECD (2014) involves the utilisation of cultural and natural heritage into development strategies, both in towns and rural areas.

In these circumstances, we can ask the following questions. How would economic and social impacts of cultural heritage restoration and preservation be evaluated? In the body of academic literature, the importance of cultural heritage is related particularly to tourism development and the associated effects - an increase in the number of tourists and the associated revenue growth, and an increase of employment and development of business activities (see e.g. MacDonald, Jolliffe, 2003; Antošová, 2016). Lapuh, Šmid Hribar (2014) defined the potential development impacts of cultural heritage in economic, social, environmental and cultural field. Lapuh, Šmid Hribar (2014) could see the economic impacts of cultural heritage protection, especially in relation to the development of heritage tourism, local business and the creation of new jobs, which could lead to an increase in household incomes. The potential social impacts of cultural heritage consist of an increase of local identity as an advantage for a local society in the era of globalisation. They also mentioned an educational role of cultural heritage for an understanding of the past. Environmental impacts are related to traditional practices in a cultural landscape leading to its conservation and ecological stability. Cultural impacts can be seen in the inclusion of cultural heritage in local development, which enables the active participation of inhabitants (Lapuh, Šmid Hribar, 2014).

In the evaluation report of the EEA Grants 2009-2014, Rampton, Carlberg, et al. (2015: 9-10) set only economic and social effects. The economic impacts included an access to cultural heritage, i.e. new visitor facilities, better wheelchair access and fire safety, better use of information and communication technologies ICT, facilities for educational or cultural activities. Also, the economic impacts are felt in employment, e.g. new jobs for restoration works with higher value and by increasing staff in new or expanded venues. However, Rampton, Carlberg, et al. (2015) expected rather a modest impact on employment. The final economic impact was defined in terms of tourism because reconstructed monuments are perceived to attract more tourists to the local area. The social impacts include improvements in image or self-perception of local communities (identity of a place), education, skills and competences, and social cohesion (Rampton, Carlberg, et al., 2015).

This paper is aimed at evaluating the economic and social impacts of the support of cultural heritage restoration in rural areas of the Czech Republic. Due to the nature of the supported 
projects, environmental impacts were not assessed. Cultural impacts are usually linked to the functioning of the community (social impacts). Generally, it is possible to assess cultural impacts of reconstructed cultural heritage from a long-term perspective, because these projects can become a valid impulse for the development of local cultural activities of inhabitants over the long-term.

\section{Definition of the evaluation tool and research methodology}

The Czech RDP 2007-2013 implemented the Measure III.2.2 Protection and Development of Rural Heritage. Within this measure, the support was focused on municipalities with up to 500 inhabitants. The support was intended for processing studies of restoration and utilisation of cultural heritage, processing regeneration programmes of protected territories and plans for landscape conservation and investments associated with maintenance, restoration and increasing the value or utilisation of cultural heritage. This included building new permanent expositions and museums with relation to local history, attractions, cultural and artistic activities and traditional folk culture. The objectives of this measure were targeted primarily to support the development of investment for greater attractiveness of rural areas and diversification of economic activities.

Under this measure, there were supported projects for restoration of historic buildings, particularly the restoration of churches and small sacral buildings that create the appearance and environment of rural municipalities. Within this measure, 988 applications were submitted; of these, 654 projects were implemented and completed, which were carried out in 542 municipalities with an average budget of EUR 83.6 thousand per project. The success rate of projects was $66.2 \%$.

Spatial distribution of projects is shown in Figure 1. The maximum number of projects was implemented in the Vysocina (91 projects), South Moravia (87) and Central Bohemia (86) regions. Localisation of projects indicates that supported municipalities are located especially in peripheral rural areas in the borderland or in the inner peripheries of the Czech Republic. Generally, it is possible to evaluate that the support was well targeted, geographically.

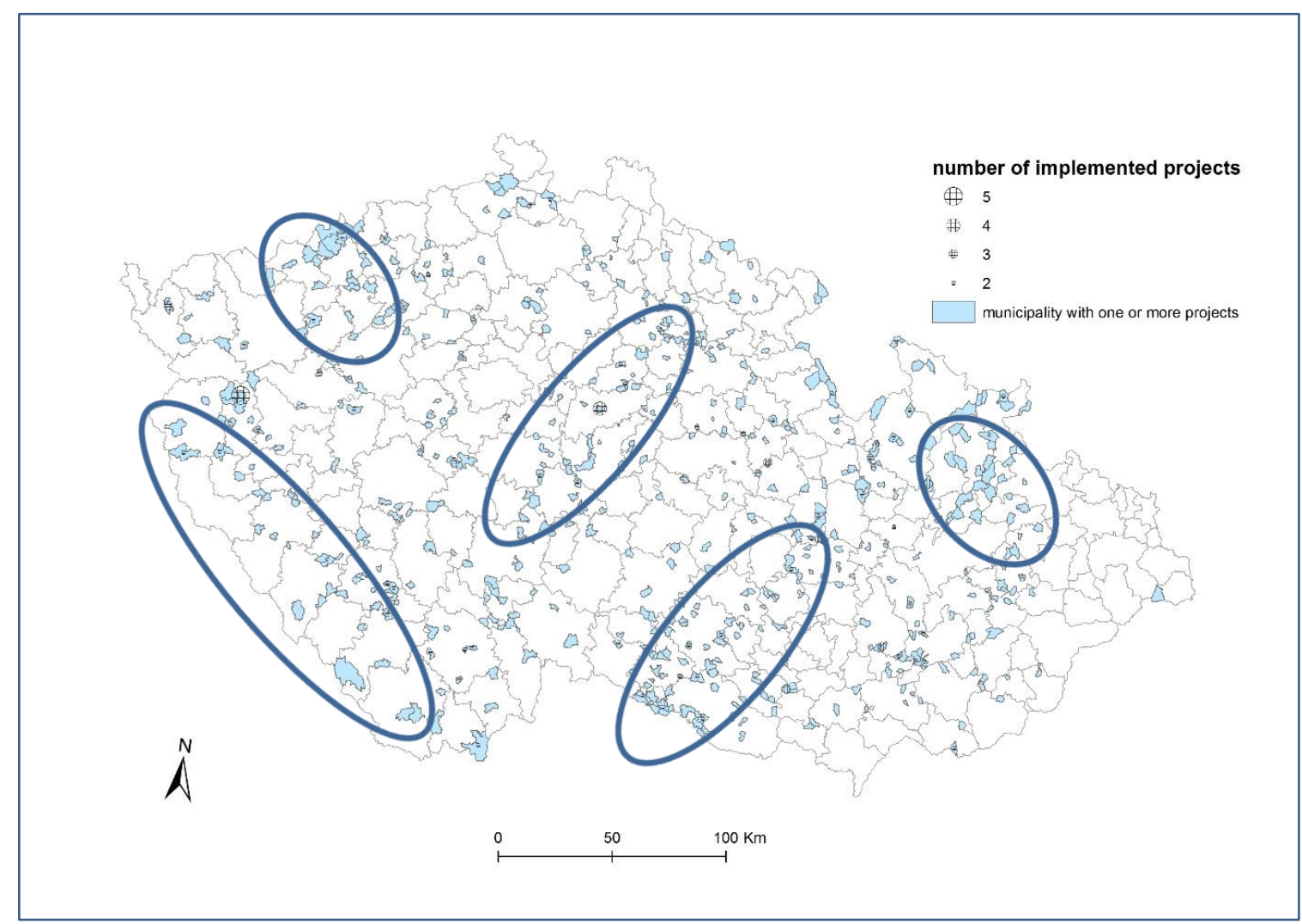

Fig 1. Localisation of supported projects focused on the restoration of cultural heritage within the measure III.2.2 of RDP 2007-2013. Source: own processing according to data of MoA/SAIF (2016) 


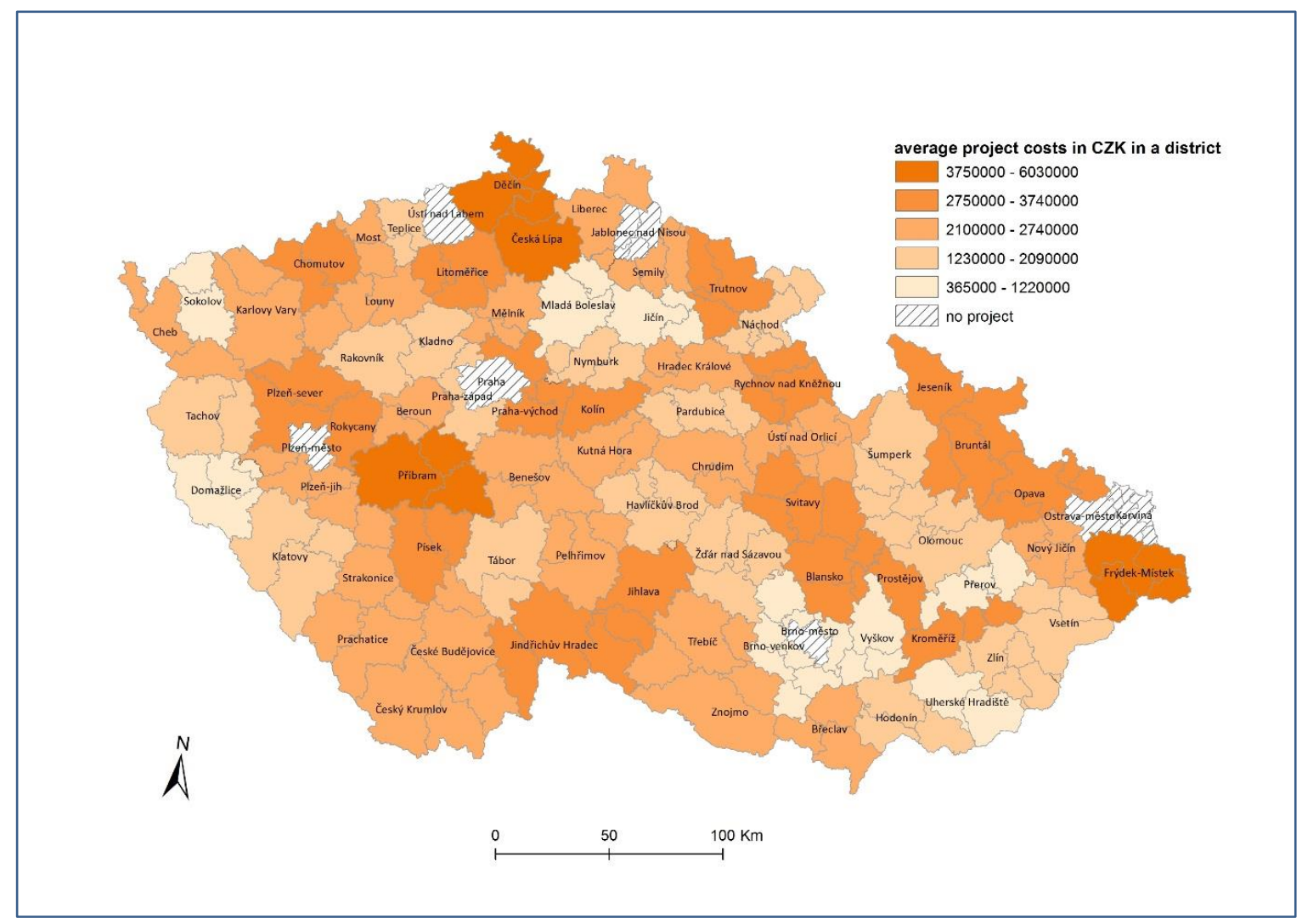

Fig 2. Average cost of a project at the level of districts (LAU I) implemented within the measure III.2.2 of RDP 2007-2013. Source: own processing according to data of MoA/SAIF (2016)

Figure 2 shows the differences in the average cost of a project at the level of districts (LAU II) in the Czech Republic. Again, marginal peripheral districts both in the borderland and inner peripheries achieved the highest values.

Project applications were submitted by municipalities, churches, religious communities and nonprofit organisations (outside the churches). The characteristics of applicants were different in particular regions of the Czech Republic. More than 50\% of applicants represented churches and religious communities (especially the Roman Catholic Church) in the South Moravian, Olomoucky, Moravian-Silesian and Vysocina Regions. The reason is that these regions have a relatively higher level of religiosity (see Table 1). In this sense, however, the Zlinsky Region is an exception, because local authorities are markedly involved in restoration of religious monuments. Nearly $2 / 3$ of projects related to religious monuments were implemented by municipalities/local authorities. This specificity of the Zlinsky Region is also influenced by, among others, a strong local identification of inhabitants with their municipality and region (Nikischer, 2013). In other regions, there were strongly represented municipalities and associations of municipalities, which eventually became local action groups. More significant representation of non-profit organisations (outside the churches) was monitored in the Pilsen Region $(21.7 \%)$ and Central Bohemia Region (18.8\%) ${ }^{2}$.

The evaluation of the impact of this measure was conducted by qualitative analysis based on data from the monitoring system of the Ministry of Agriculture (MoA)/ State Agricultural Intervention Fund (SAIF), statistical data and the results of a questionnaire and telephonic survey. The questionnaire survey was conducted in June 2016 and involved all 577 final beneficiaries (some beneficiaries realised more than 1 project). The rate of return was $29.46 \%(n=170)$. The achieved sample was fully representative with regard to a geographical distribution of projects and also to types of supported beneficiaries.

\footnotetext{
2 This is due to the fact that, among other reasons, property owners founded the non-profit organisation (foundation) because of the possibility of receiving subsidies.
} 
Tab 1. The share of believers and projects implemented by churches or religious communities in regions of the Czech Republic. Source: Census 2011, Czech Statistical Office, SAIF, own calculation

\begin{tabular}{|l|r|r|}
\hline \multicolumn{1}{|c|}{ Region } & $\begin{array}{c}\text { The share of believers, } \\
\text { belonging to churches, religious } \\
\text { communities in \% }\end{array}$ & $\begin{array}{c}\text { The share of projects } \\
\text { implemented by churches, } \\
\text { religious communities in \% }\end{array}$ \\
\hline Praha & 10.8 & 42.4 \\
\hline Central Bohemia & 8.6 & 66.7 \\
\hline South Bohemia & 13.5 & 25.0 \\
\hline Pilsen & 9.2 & 18.2 \\
\hline Karlovarsky & 6.9 & 25.5 \\
\hline Ustecky & 5.2 & 33.3 \\
\hline Liberecky & 7.2 & 19.6 \\
\hline Kralovehradecky & 10.3 & 45.2 \\
\hline Pardubicky & 13.6 & 57.4 \\
\hline Vysocina & 22.7 & 52.9 \\
\hline South Moravia & 20.6 & 56.7 \\
\hline Olomoucky & 16.4 & 40.0 \\
\hline Zlinsky & 29.0 & 63.2 \\
\hline Moravian-Silesian & 18.2 & 46.0 \\
\hline Czech Republic & 13.9 & \\
\hline
\end{tabular}

It is noteworthy that, due to the focus of Measure III.2.2, no projects were implemented in districts of large cities (Prague, Brno, Ostrava, Plzen, Usti nad Labem) and in the districts of Karvina and Jablonec nad Nisou. This was influenced by the structure of appropriate municipalities of these districts, which all had more than 500 inhabitants. In the qualitative responses, respondents assessed the impacts of project implementation on a 1-5 scale (1 - minimal importance, 5 - maximum importance) or 0 (I do not know, I cannot answer). In the following telephonic survey, those final beneficiaries who did not participate in the questionnaire survey were interviewed. Also, these respondents were selected on the basis of territorial keys (at the district level). A total of 32 respondents were interviewed - final beneficiaries from municipalities (20), parishes/ religious organisations (9) and non-profit organisations outside the churches (3).

\section{Results and discussion}

According to Rampton, Carlberg, et al. (2015), the results of their analysis were divided into economic and social impacts. The last part of this chapter is devoted to an evaluation of the ability of the final beneficiary to implement appropriate projects without the support of Measure III.2.2.

\subsection{Economic impacts}

Rampton, Carlberg, et al. (2015) defined three areas of economic impacts, i.e. the access to cultural heritage, employment and increase in tourism. In respect of access to cultural heritage, it is necessary to take into account the type of supported projects. The majority of projects dealt with the restoration of churches and religious monuments (chapels, waysides, sculptures), which are open for visitors and residents, either freely or at a specified time (during the holding of Masses, pilgrimages, etc.). These restored historic buildings become places of implementation of local religious, educational or cultural activities.

Regarding employment, this measure did not directly focus on job creation. On the other hand, job creation was a preferential criterion, which increased the chance of getting financial support. For this reason, the MoA data showed 79 newly created jobs as a direct result of supported projects. This means a rate of 0.12 jobs per one project (total number of projects was 654). In the telephonic survey, respondents, who created jobs in their projects, confirmed their intent on 
keeping to the criteria. Regarding the new jobs created in connection with the project implementation, the questionnaire survey respondents indicated 141.7 created jobs $(0.22$ jobs per project). These jobs were divided into tourism -55 jobs, craft -22 jobs, retail -16.2 jobs, and 48.5 jobs in other branches. ${ }^{3}$ The total number of newly created jobs may seem to be relatively small. However, the character of supported projects was focused more on the improvement of the overall village appearance and cultivation of its environment. In this context, the number of created jobs can be assessed positively.

The influence of the monument restoration on the development of tourism was evaluated by the respondent (on the scale 1-5 where 1 means minimal importance, 5 means maximum importance) or 0 (I do not know, I cannot answer). This question was primarily about the perception of final beneficiaries about the impacts of their projects on a given locality. The results were slightly above the average (see Table 2$)^{4}$.

Tab 2. The perception of final beneficiaries about the impacts of their projects on tourism development in a given locality. Source: own elaboration

\begin{tabular}{|l|r|r|}
\hline Project was implemented in & $\begin{array}{c}\text { Number of } \\
\text { respondents }\end{array}$ & $\begin{array}{c}\text { Perception of final beneficiaries about } \\
\text { the impacts of their projects on tourism } \\
\text { development in a given locality }\end{array}$ \\
\hline Conservation area & 1 & 2.0 \\
\hline Conservation zone & 16 & 3.3 \\
\hline Landscape conservation area & 2 & 4.0 \\
\hline Protected landscape area & 14 & 3.2 \\
\hline National park & 3 & 2.7 \\
\hline Natural park & 8 & 3.3 \\
\hline Locality of NATURA 2000 & 4 & 3.8 \\
\hline Other locality with high natural value & 16 & 2.8 \\
\hline Other localities & 73 & 2.9 \\
\hline
\end{tabular}

Note: Respondents assessed the impacts of project implementation on a 1-5 scale (1 - minimal importance, 5 - maximum importance) or 0 (I do not know, I cannot answer).

Table 2 shows numbers of respondents under location of the project implementation and their perception about the project's impacts on tourism development. It is necessary to note that there are low number of answers from respondents particularly in landscape conservation areas and zones, localities of Natura 2000 and national parks. Therefore, the assessment of the project's importance for tourism development is not entirely conclusive. Nevertheless, the highest number of projects was implemented in areas which are neither natural nor culturally protected. In these localities, the respondents evaluated an increasing interest of tourists that was only slightly above the average.

According to the questionnaire (answered by 65 respondents), the importance of the impact on municipal budget revenues caused by supported projects was marginal. Average assessment was approximately 1.5 on a 5 -point scale ( 1 - minimal importance, 5 - maximal importance). In the telephonic survey, respondents confirmed this finding. ${ }^{5}$ The significance of the project implementation for the sales / turnover of business entities was assessed as slightly better (average 1.8), but it is considered to be marginal. This result was also confirmed in telephonic interviews. Therefore, it can be concluded that the majority of implemented projects did not have significant economic impacts on municipalities and business entities in localities.

\footnotetext{
${ }^{3}$ Total of 67 respondents answered this question, of which only 55 respondents gave a concrete number of jobs created. Others were unable to assess whether jobs had been created, or they indicated that there was no job.

${ }^{4}$ In Table 2, there are included only those respondents who answered both questions and who were also able to assess the impacts of the projects on tourism development in a given locality, were included.

${ }^{5}$ With the exception of one respondent from a municipality, who controls a boarding house in a historic building of the former school. The municipality also offers spaces for various social and cultural activities for rent.
} 
Table 3 shows a perception of final beneficiaries about the impacts of their projects on tourism development in a given locality, perception of final beneficiaries about the importance of their projects for tourists and the establishment of economic activities in municipalities at the level of regions. Respondents from the Zlinsky and Karlovarsky regions perceived the increasing impact of their projects on tourism development. In these regions, there is also the highest assessment of the establishment of new economic activities in municipalities. However, overall assessment of the new economic activities creation (services, tourism) is below-average. The importance of implemented projects for tourists and the increasing impact on tourism development seem to be overvalued in comparison with data on tourism from the Czech Statistical Office.

Tab 3. The influence of the project implementation on tourism development. Source: Czech Statistical Office, SAIF, questionnaire survey, own calculation

\begin{tabular}{|c|c|c|c|c|c|}
\hline Region & $\begin{array}{c}\text { Number } \\
\text { of } \\
\text { projects }\end{array}$ & $\begin{array}{l}\text { Perception of final } \\
\text { beneficiaries about } \\
\text { the impacts of their } \\
\text { projects on tourism } \\
\text { development in a } \\
\text { given locality }\end{array}$ & $\begin{array}{l}\text { Importance of } \\
\text { project } \\
\text { implementation } \\
\text { for tourists }\end{array}$ & $\begin{array}{c}\text { New } \\
\text { economic } \\
\text { activities }\end{array}$ & $\begin{array}{c}\text { Increase of guests' } \\
\text { number in } \\
\text { accommodation } \\
\text { facilities in region } \\
\text { (index } 2013 / 2007 \text { ) }\end{array}$ \\
\hline South Moravian & 87 & 2.71 & 3.06 & 1.62 & 1.001 \\
\hline Vysocina & 91 & 3.44 & 3.08 & 2.00 & 0.901 \\
\hline South Bohemia & 72 & 3.18 & 3.00 & 1.75 & 1.048 \\
\hline Pilsen & 60 & 3.00 & 2.86 & 2.33 & 0.984 \\
\hline Kralovehradecky & 51 & 3.17 & 2.93 & 1.83 & 0.974 \\
\hline Pardubicky & 42 & 2.57 & 3.71 & 1.50 & 0.871 \\
\hline Liberecky & 15 & 3.33 & 3.33 & $\mathrm{x}^{*}$ & 0.958 \\
\hline Olomoucky & 60 & 2.55 & 2.70 & 1.80 & 1.015 \\
\hline Zlinsky & 25 & 3.67 & 4.00 & 2.50 & 0.970 \\
\hline $\begin{array}{l}\text { Moravian- } \\
\text { Silesian }\end{array}$ & 38 & 2.80 & 3.17 & 2.00 & 0.943 \\
\hline Central Bohemia & 86 & 3.16 & 2.73 & 2.46 & 0.961 \\
\hline Ustecky & 48 & 3.10 & 2.22 & 2.22 & 0.998 \\
\hline Karlovarsky & 11 & 3.50 & 3.00 & 2.50 & 1.104 \\
\hline
\end{tabular}

* In the Liberecky Region, only one respondent assessed this question. Therefore, his assessment is not mentioned. Note: Respondents assessed the impacts of project implementation on a 1-5 scale (1 - minimal importance, 5 maximum importance) or 0 (I do not know, I cannot answer).

Respondents of the telephonic survey emphasised that projects were primarily aimed at the restoration of historical monuments without a direct relation to tourism development. Tourists usually just pass through supported villages which had improved their appearance. Following Crouch (2006), the preservation of the aesthetics of the rural cultural heritage contributes to the potential development of local tourism. Supported rural municipalities will present what rurality means.

\subsection{Social impacts}

Rampton, Carlberg, et al. (2015) suggested that social impacts of cultural heritage protection include improvements in image or self-perception of local communities (identity of a place), education, skills and competences, and social cohesion. The rate of the sense of belonging of inhabitants to the municipality / micro-region after the project implementation according to the respondents increased very little (a difference before and after the project implementation is about 0.6 of a point). In view of the importance of project implementation for individual groups, respondents (in both the questionnaire and telephonic survey) evaluated both inhabitants and visitors by using the same value (3.5). Only $55 \%$ of participating respondents expressed their opinion about the significance of the project implementation for entrepreneurs; the assessment showed low importance for entrepreneurs (1.8). Respondents could select another group of 
actors of local development; this selection was carried by only $8 \%$ of participating respondents with a slightly above-average evaluation of 3.7. In their comments, they mentioned particularly religious communities and the overall importance of the project as being the reason(s) for the appearance of the village.

There are differences in terms of the importance of the project implementation for residents and strengthening the sense of belonging to the municipality / micro-region, which should be supported by the implementation of the project. The importance of the project for residents was best appreciated by respondents from the Liberecky and Zlinsky regions, followed by respondents from the Pardubicky region. The Pardubicky and Liberecky regions also achieved the highest values in evaluation of projects with the aim of strengthening the sense of belonging to the municipality / micro-region. Conversely, low values of assessment of both questions are shown in the Karlovarsky and Ustecky regions where rural areas have, over the long-term, belonged to economically and socially problematic territories in the Czech Republic.

According to the opinion of respondents in the questionnaire survey, there was a slight increase in the interest of inhabitants in the protection of cultural heritage (average assessment of 3.4, number of respondents 170). Also, projects contributed ${ }^{6}$ to the revival or expansion of old traditions (59\% of respondents who answered this question), to the development of children leisure activities (30\%), to the expansion of existing clubs and societies (26\%), to the creation of new traditional events which are now organised regularly/annually (24\%). Only 6\% of respondents mentioned the establishment of new clubs and societies, and $19 \%$ of respondents indicated other events, e.g. concerts in churches, churches nights, and services for the disabled. These findings were confirmed by the telephonic survey, but answers differed by a type of respondent (municipality, church, non-profit organisation) and by a focus of the project. While municipalities were more accentuated in the overall importance of the project for all residents of the village, churches and religious communities emphasised the importance of projects for spiritual development, especially with respect to believers, and the cultivation of an environment for religious activities.

In summary, the projects clearly contributed to maintaining or restoring those activities of the local culture and to strengthening social cohesion in supported municipalities.

\subsection{Deadweight effect - the ability of beneficiaries to implement the project without the public funding}

Within the telephonic survey, respondents were also asked to estimate the probability of the project implementation without the support within Measure III.2.2 of the RDP 2007-2013. The appropriate question also included the context and reasons according to different types of respondents. Responses were very different according to the type of beneficiary implementing the project, i.e. municipalities, churches and religious communities, and non-profit organisations.

Municipalities implemented various projects - restoration of historic buildings (schools, parishes, granaries, etc.), restoration of churches, chapels, and also small monuments (statues and sculptures) that are owned by the municipality. In addition, municipalities implemented landscaping measures in the surroundings of these monuments. Eleven municipalities indicated that they would not be able to implement the project without the support of RDP. This was caused, mainly, by the low budget of small municipalities with limited sources for investments. Three respondents of the nine remaining municipalities could not specify the probability of the project implementation without the support of RDP. They emphasised that it would certainly not be possible to carry out all the work in the same range and the work would have to be undertaken gradually. Only three respondents estimated the probability of the project implementation as 20$30 \%$, but again they mentioned the need to proceed with it in stages (extension of the implementation period), and to perform only the most necessary reconstruction works. Three respondents estimated the probability of the project realisation as up to $50 \%$. In all three cases, they were repaired religious monuments - a chapel, a memorial pillar, statues of saints, and landscaping around these monuments. According to these respondents (mayors of these

\footnotetext{
6 Total number of respondents who answered this question was 145. Respondents could select more possibilities.
} 
municipalities), these repairs were necessary and urgent and the municipality would have to put up the money for them. But, again, they mentioned the need to proceed with them in stages. Therefore, they welcomed the opportunity to use subsidies of the RDP.

Churches and religious communities (the Catholic Church was dominant) were mainly implementing repairs to churches and prayer houses, and in one case, the reconstruction of a monastery. Four of the nine respondents explained that they would not be able to implement the project. They pointed to the financial demands of repairs and the limited financial resources of the church. The other two respondents mentioned the need to proceed in stages and they were unable to determine the probability of the project implementation without the support of the RDP. Two projects had a chance to be implemented without the support of the RDP at the level of 10$20 \%$; only one respondent estimated the project probability as being up to $50 \%$. This project was aimed at a complete reconstruction of the church, a historical monument of local importance in the protected landscape area. The respondent emphasised that without the subsidy from the RDP it would be necessary to reconstruct the church in stages and estimated the period of gradual reconstruction as being 10 years. Non-profit organisations also expressed a very low probability of the project implementation without support. Only one non-profit organisation would implement the project of restoration of the castle grounds without the support of the RDP. The reason was, however, clearly formulated within a long-term business plan for the commercial use of the monument.

Therefore, in rural municipalities of up to 500 inhabitants, it would be very complicated to implement projects of cultural heritage protection without public support. Overall, the probability of project implementation was only $16.2 \%$ without subsidies within the bounds of Measure III.2.2. Differences among individual respondents were huge. These differences are determined by the type of final beneficiary and their particular financial capacity. All respondents of the telephonic survey perceived the importance of the cultural heritage restoration, but most of them could not implement the project from their own funds. Municipalities understood the importance of cultural heritage, especially in social terms, and to a lesser extent in economic terms. On the other hand, due to limited municipal budgets, municipalities themselves were not able to finance these projects. There were logical exceptions, i.e. projects having the potential for direct commercial use.

The settlement structure of the Czech Republic is very fragmented (Wokoun et al., 2011) and is comparable to a residential structure in France, Greece and Slovakia. The consequence of this structure is a high number of small municipalities with low budgets, which do not generate the necessary critical mass, and even within local club activities they do not generate the necessary funds for the restoration of the local cultural heritage. This situation is most significantly reflected in peripheral rural areas of the territory that resettled after the Second World War, especially in the Ustecky and Karlovarsky regions.

\section{Conclusion}

Cultural heritage can become an important element in the development of the territory, not only in towns but also in rural areas. The European Union formulated for the period of 2007-2013 a separate rural development policy, which predominantly supported multifunctional agriculture. But, under Axis III, one measure was aimed at protecting cultural heritage (see Council Regulation (EC) no. 1698/2005 Art. No. 57).

The Czech Republic, as well as other Central European countries (except Slovakia), applied this measure in rural municipalities with up to 500 inhabitants. These small municipalities contend with a shortage of investment funds, which often leads to a gradual deterioration and to the devastation of cultural heritage in their territory. The implemented projects focused mainly on the restoration and reconstruction of historical monuments, churches, cemeteries and small sacral monuments, which improve an environment in rural settlements. This paper has aimed at evaluating the economic and social impacts of the implementation of Measure III.2.2 of the Czech RDP 2007-2013. 
According to the accomplished surveys, the importance of economic impacts is not crucial. Generally, respondents perceived only limited effects on tourism development and related new economic activities. The impact on municipal budget revenues caused by supported projects was marginal. Implementation of the projects was not conditioned by the creation of new jobs. Nevertheless, some jobs ( 0.12 jobs per a project) were created and maintained within supported projects. Other job positions created outside of the supported projects ( 0.22 jobs per a project) can be perceived as a positive externality. According to the assessment of respondents, the number of tourists has increased only in some supported municipalities due to an improvement of the appearance of monuments and overall aesthetic cultivation of the villages. It is also very important for residents. But most of the projects could not be implemented due to a lack of their own funds of respondents. Overall probability of project implementation was only $16.2 \%$ without public support and it was influenced by a type of a final beneficiary and by a possible commercial potential of the project.

RDP 2007-2013 did not require economic impact of restored monuments in terms of their utilisation for the development of economic activities. Nevertheless, if such a plan / concept existed, the economic impact of supported projects could be more significant. The literature review of this paper has shown the importance of the cultural heritage inclusion into development strategies at regional and local levels (OECD, 2014; Kloosterman, 2014). But development strategies based on the rural cultural heritage are not usual in the Czech Republic, as is commonplace in some Northern or Western European countries, e.g. Norway (Lysgård, 2016) and France (Ducros, 2014).

Social impacts of the projects lie in strengthening the identification and social cohesion of inhabitants. This includes, especially, positive effects on the community through an interest in the project implementation, and participation in the project through volunteer works. Supported projects started to develop social and cultural activities in restored buildings that became centres of community life. It was mainly about the revival of old traditions or the creation of new traditions and the development of leisure activities for children. A specific benefit for believers, was the reuse of sacral monuments for religious ceremonies (the improvement of the availability of religious services). In effect, therefore, the protection of cultural heritage became an important soft tool of the EU rural development policy in the period of 2007-2013. Thus, in the Czech Republic the support of cultural heritage contributed rather to the "lived-in cultural heritage" concept according to Wang (2016).

Support of rural cultural heritage proved to be a suitable tool of RDP 2007-2013 with partial economic, but primarily social impacts. Nevertheless, the EU Rural Development Policy does not support this tool in the programming period of 2014-2020. In the Czech Republic, it is possible to support cultural heritage in the framework of integrated regional development in the programming period of 2014-2020. This tool is partially contained in the Integrated Regional Operational Programme (IROP). However, IROP is primarily focused on revitalising the set of monuments listed on the UNESCO World Heritage list of monuments or on the indicative list of World Heritage sites in the category of cultural heritage, as well as national cultural monuments and sites registered in the indicative list of national cultural heritage, both of them up to 1 st January 2014 (MMR, 2014). It means that this program does not include small monuments in rural areas. Particularly, small municipalities, especially, but also churches and non-profit organisations have lost an important financial source for the restoration of their cultural heritage. The question is how they will continue the restoration of their local cultural heritage, which has neither global nor national importance, but is very important for local communities.

How will the Czech Republic (or regions and municipalities) solve this problem? The way to tackle this issue could be through an inclusion of the cultural heritage restoration into the development strategies with a clear conception of the concrete use of cultural heritage for the development of the municipality or region (Lysgård, 2016; Kloosterman, 2014; OECD, 2014). In this sense, it is not only about a relation to tourism, but also about the importance of cultural heritage in the context of local identity, and its usage for various traditional events for the residents of the municipality and catchment villages. These interventions have particularly strong social impacts, i.e. in relation to building or strengthening the genius loci and the local social cohesion. According to Šmid Hribar and Lozej (2013, p. 377) "interconnection of various cultural values and 
cooperation between various stakeholders that can effectively obtain, activate, and enhance local resources (both financial and human) are key to effective sustainable management". Therefore this issue could be included in the methodology of development strategies.

With regard to the decline in public funding (particularly in the EU), it will be more necessary to combine more the public national / multinational funds with the mobilisation of local public and private sources. But, this situation can be unsolvable for small municipalities with their limited budgets. The solution can be to incorporate the cultural heritage into micro-regional strategies with impacts on greater interconnection and financial participation of actors at a municipality / microregion. The joining of financial resources within the municipality/micro-region that is associated with a specific conception of the concrete usage and benefits of monuments can be a way to achieve economic and social impacts in restoring entities of local cultural heritage.

\section{Acknowledgements}

This work was funded by the Czech Science Foundation (GACR) under Grant 17-12372S with a title "Theoretical and Methodological Perspectives of the EU's Neoproductivist Rural Development Policy", and by the Ministry of Agriculture of the Czech Republic, Rural development programme 2014-2020 (Technical Assistance - "Ex-post evaluation of the Czech Rural Development Programme 2007-2013").

\section{Academic references}

[1] Alumäe, H., Prinstmann, A. \& Palang, H. (2003). Cultural and Historical Values in Landscape Planning: Locals' Perception. In Palang, H., Fry, G., eds., Landscape Interfaces Cultural Heritage in Changing Landscapes (pp. 125-145). Dordrecht: Kluwer.

[2] Antošová, G. (2016). Cultural rural development in the Czech Republic (Case study of the Liberec region). European Countryside 8(3), 263-277. DOI: 10.1515/euco-2016-0019.

[3] Asztalos Morell, I. (2014). "I do not understand how I became a farmer": The small-peasant path to family farm enterprise in post-socialist rural Hungary. Development Studies Research 1(1), 88-99, DOI: 10.1080/21665095.2014.916188.

[4] Bell, D. \& Jayne, M. (2010). The creative countryside: Policy a practice in the UK rural cultural economy. Journal of Rural Studies 26, 209-218. DOI: 10.1016/j.jrurstud.2010.01.001.

[5] Bičík, I. \& Jančák, V. (2005). Transformační procesy v českém zemědělství po roce 1990. Praha: Charles University.

[6] Chaplin, H., Gorton, M. \& Davidova, S. (2007). Impediments to the Diversification of Rural Economies in Central and Eastern Europe: Evidence from Small-scale Farms in Poland, Regional Studies 41(3), DOI: 10.1080/00343400701282129.

[7] Chromý, P., Jančák, V., Marada, M. \& Havliček, T. (2011). Venkov - žitý prostor: regionální diferenciace percepce venkova představiteli venkovských obcí v Česku. Geografie 116(1), 23-45.

[8] Chromý, P. \& Janů, H. (2003). Regional identity, activation of territorial communities and the potential odf the development of peripheral regions. Acta Universitatis Carolinae Geographica 38(1), 105-117.

[9] Courtney, P., Hill, G. \& Roberts, D. (2006). The role of natural heritage in rural development: An analysis of economic linkages in Scotland. Journal of Rural Studies 22(4), 469-484. DOI: 10.1016/j.jrurstud.2006.02.003.

[10] Crouch, D. (2006). Tourism, consumption and rurality. In Cloke, P., Marsden, T. \& Mooney, P., eds., The Handbook of Rural Studies (pp. 355-363). Thousand Oaks, CA: Sage Publications.

[11] Čapkovičová, A. (2016). Transformation of the employment base in Czech rural regions, Regional Studies, Regional Science 3(1), 229-238. DOI: 10.1080/21681376.2016.1165626. 
[12] Daugstad, K., Rønningen, K. \& Skar, B. (2006). Agriculture as an upholder of cultural heritage? Conceptualizations and value judgements - A Norwegian perspective in international context. Journal of Rural Studies 22(1), 67-81. DOI: 10.1016/j.jrurstud.2005.06.002.

[13] Dolista, J. (2006). Religiozita v českém prostředí a v pohraničí. In: Majerová, V., ed., Venkov je náš svět (pp. 304-306). Praha: Česká zemědělská univerzita.

[14] Ducros, H. (2014). Protect, Promote, Develop: Rural Tourism and Village Patrimonialisation in France. In Dashper, K., ed., Rural Tourism: An International Perspective (pp. 59-78). Cambridge: Cambridge Scholars Publishing.

[15] Hinterstoisser, H. (2001). The rural heritage as a main factor for development The multifunctionality of landscapes in rural areas in Austria. Naturopa 95, 10-11.

[16] Heřmanová, E., Chromý, P. et al. (2009). Kulturní regiony a geografie kultury. Praha: ASPI.

[17] Ilbery, B. et al. (1998). The Geography of Rural Change. Upper Saddle River, NJ: Pearson Education.

[18] Jablonská, L. (2005). Udržitelná minulost? Aneb sídelní ráz versus regulace. In Venkov, jeho proměny a územní plánování (pp. 50-56). Brno: Ústav územního rozvoje.

[19] Johnson, M. T. (2013). Evaluating Culture: Well-Being, Institutions and Circumstance. New York: Palgrave MacMillan. DOI: 10.1057/9781137313799.

[20] Keitsch, M. M., Kua, H. W. \& Skjerven, A. (2016). Special Issue: The Cultural Dimension of Resilience and Sustainability. Sustainable Development 24, 273-274. DOI: $10.1002 / \mathrm{sd} .1627$.

[21] Kloosterman, R. C. (2014). Cultural Amenities: Large and Small, Mainstream and Niche A Conceptual Framework for Cultural Planning in an Age of Austerity. European Planning Studies 22(12), 2510-2525. DOI: 10.1080/09654313.2013.790594.

[22] Labadi, S. (2013). UNESCO, Cultural Heritage, and Outstanding Universal Values. Valuebased Analyses of the World Heritage and Intangible Cultural Heritage Conventions. Plymouth: AltaMira Press.

[23] Lapuh, L. \& Šmid Hribar, M. (2014). Cultural heritage: the driver of development. In Nared, J. \& Razpotnik Viskovic, N., eds., Managing Cultural Heritage Sites in Southeastern Europe (pp. 19-22). Ljubljana: Geografski inšitut Anatona Malika ZRC SAZU.

[24] Lee, J., Árnason, A., Nightingale, A. \& Shucksmith, M. (2005). Networking: Social Capital and Identities in European Rural Development. Sociologia Ruralis 45(4), 267-283. DOI: $10.1111 / \mathrm{j} .1467-9523.2005 .00305 . \mathrm{x}$.

[25] Lempert, D. (2015). Classifying heritage by states of decay, restoration, and transformation for tourism, teaching, and research: 'un-freezing' sites in time to reveal additional meanings. Journal of Heritage Tourism 10(4), 378-398. DOI: 10.1080/1743873X.2014.994637.

[26] Lysgård, H., K. (2016). The 'actually existing' cultural policy and culture-led strategies of rural places and small towns. Journal of Rural Studies 44, 1-11. DOI: 10.1016/j.jrurstud.2015.12.014.

[27] MacDonald, R. \& Jolliffe, L. (2003). Cultural rural tourism. Evidence from Canada. Annals of Tourism Research 30(2), 307-322. DOI: 10.1016/S0160-7383(02)00061-0.

[28] Majerová, V. (2007). Social factors influencing the differences between developed and less developed regions. Agricultural Economics (Zemědělská ekonomika) 53(11), 513-517.

[29] Majerová, V., Pavlíková, G. \& Maříková, P. (2010). Current social structure of agricultural workers in the Czech Republic. Agricultural Economics (Zemědělská ekonomika) 56(11), 508-521.

[30] Marková, B. \& Tichá, I. (2011). The Impact of Globalization on Cultural Policy: A Case Study of the City of Ostrava. In Mácha, P. \& Drobík, T., eds., The Scale of Globalization. Think 
Globally, Act Locally, Change Individually in the 21st Century (pp. 207-212). Ostrava: University of Ostrava.

[31] Mettepenningen, E., Vandermeulen, V., Van Huylenbroeck, G., Nick Schuermans, N., Van Hecke, E., Messely, L., Dessein, J. \& Bourgeois, M. (2012). Exploring Synergies between Place Branding and Agricultural Landscape Management as a Rural Development Practice. Sociologia Ruralis, 52(4), 432-452. DOI: 10.1111/j.1467-9523.2012.00575.x.

[32] Nikischer, R. (2013). Teritoriálna identita obyvatel'ov Česka a Slovenska, Geografie 118(3), 243-264.

[33] Patočka, J. \& Heřmanová, E. (2008). Lokální a regionální kultura v České republice. Praha: ASPI.

[34] Pělucha, M. et al. (2012). Venkov na prahu 21. století. Praha: Alfa.

[35] Pek, T. (2009). Stavební památky - Specifika prípravy a financování jejich obnovy, údržby a provozu. Praha: Wolters Kluwer.

[36] Pospěch, P. (2014). Discursive no man's land: Analysing the discourse of the rural in the transitional Czech Republic. Journal of Rural Studies 34, 96-107. DOI: 10.1016/j.jrurstud.2014.01.006.

[37] Ray, C. (1998). Culture, Intellectual Property and Territorial Rural Development, Sociologia Ruralis 38(1), 3-20. DOI: 10.1111/1467-9523.00060.

[38] Rampton, J., Carlberg, M. et al. (2015). Mid-term evaluation of the sector cultural heritage under the EEA grants, 2009-2014. [A final report]. Oxford: Centre for Strategy and Evaluation Services.

[39] Sarris, A. H, Doucha, T. \& Mathijs, E. (1999). Agricultural restructuring in Central and Eastern Europe: implications for competitiveness and rural development. European Review of Agricultural Economics 26(3), 305-329. DOI: 10.1093/erae/26.3.305.

[40] Shipley, R. \& Feick, R. (2009). A Practical Approach for Evaluating Cultural Heritage Landscapes: Lessons From Rural Ontario, Planning Practice \& Research 24(4), 455-469. DOI: 10.1080/02697450903327113.

[41] Sklenička, P. (2006). Applying evaluation criteria for the land consolidation effect to three contrasting study areas in the Czech Republic. Land Use Policy 23()4, 502-510. DOI: 10.1016/j.landusepol.2005.03.001.

[42] Sokol, M. (2001). Central and Eastern Europe a Decade After the Fall of State-socialism: Regional Dimensions of Transition Processes. Regional Studies, Vol. 35, No. 7, pp. 645655. DOI: $10.1080 / 00343400120075911$.

[43] Spousta, J. (2002). Changes in Religious Values in the Czech Republic. Sociologický časopis/Czech Sociological Review, Vol. 38, No. 3, pp. 345-363.

[44] Stenseke, M. (2000). Whose landscape values? Central goals versus local perspectives in planning and management of the rural landscape. In Haartsen, T., Groote, P. \& Huigen, P.P.P., eds., Claiming Rural Identities. Dynamics, Contexts, Policies. Assen: Van Gorcum.

[45] Šifta, M. \& Chromý, P. (2014). Symboly a identita regionu: Analýza vnímání prírodních symbolů oblastí s intenzivně přeměněnou krajinou v Česku. Geografický časopis 66(4), 401415.

[46] Šmid Hribar, M., Bole, D. \& Pipa, P. (2015). Sustainable heritage management: social, economic and other potentials of culture in local development. Procedia - Social and Behavioral Sciences, Vol. 188, pp. 103-110, DOI: 10.1016/j.sbspro.2015.03.344.

[47] Šmid Hribar, M. \& Lozej, Š. L. (2013). The role of identifying and managing cultural values in rural development. Acta geogaphica Slovenica 53(2), 371-378.

[48] Vaishar, A. \& Zapletalová, J. (2016). Regional identities of Czech historical lands. Hungarian Geographical Bulletin 65(1), 15-25. DOI: 10.15201/hungeobull.65.1.2. 
[49] Věžník. A. \& Bartošová, L. (2004). Selected regional differences of the Czech Republic agriculture after the transformation processes. Agricultural Economics 50(5), 207-216.

[50] Wang, Y. (2016). A Sustainable Approach for Post-Disaster Rehabilitation of Rural Heritage Settlements. Sustainable Development 24(5), 319-329. DOI: 10.1002/sd.1632.

[51] Woods, M. (2011). Rural. Abingdon: Taylor \& Francis.

[52] Wokoun, R., Kourilova, J., Pelucha, M. \& Kveton, V. (2010). Prospective Future Trends in Urban - Rural Relationships within the Territorial Agenda of the EU: A Critical Analysis of Implementation with a Special Focus on the Example of the Czech Republic. European Planning Studies 18(11), 1881-1896. DOI: 10.1080/09654313.2010.512172.

[53] Wokoun, R. et al (2011). Základy regionálních věd a veřejné správy. Plzeň: Aleš Čeněk.

[54] Zeman, K. (2013). Vývoj vlastnictví k půdě a souvisejících procesů na území ČR od roku 1918 do současné doby. Praha: Oeconomica.

\section{Other sources}

[55] European Council (2005). Council Regulation (EC) no. 1698/2005 of 20 September 2005 on supporting the development of rural areas by the European Agricultural Fund for Rural Development (EAFRD). Retrieved from: http://eur-lex.europa.eu/legalcontent/EN/TXT/PDF/?uri=CELEX:32005R1698\&from=EN [accessed by 2017-01-10].

[56] European Council (2007). Resolution of the Council of 16 November 2007 on a European Agenda for Culture. 2007/C 287/01. Retrieved from: http://eur-lex.europa.eu/legalcontent/EN/TXT/?uri=CELEX:32007G1129\%2801\%29 [accessed by 2017-01-15].

[57] European Comission (2014). Towards an integrated approach to cultural heritage for Europe. Communication from the Commission to the European Parliament, the Council, the European Economic and Social Committee and the Committee of the Regions. COM (2014) 477. Retrieved from:

http://ec.europa.eu/assets/eac/culture/library/publications/2014-heritage-

communication_en.pdf [accessed by 2017-01-10].

[58] ESPON (2013). EDORA (European Development Opportunities for Rural Areas).Applied Research Project 2013/1/2. Retrieved from:

https://www.espon.eu/export/sites/default/Documents/Projects/AppliedResearch/EDORA/e dora_inception_report-full.pdf [accessed by 2017-01-15].

[59] European Network for Rural development (2014). Rural Development Programme 20072013 of Austria. State of the Total Public and EAFRD expenditure per measure. Retrieved from:

https://enrd.ec.europa.eu/sites/enrd/files/assets/pdf/monitoring_indicators/financial_and_ph ysical_indicators/rdp/b_financial-expenditure-2014_at.pdf [accessed by 2017-01-15].

[60] Ministry of Agriculture and Rural Development of Hungary (2007). New Hungary Rural Deveploment Programme. Retrieved from: http://www.terport.hu/webfm_send/3141 [accessed by 2017-01-15].

[61] Ministry of Agriculture and Rural Development of Poland (2007). Rural Development Programme for 2007-2013. Retrieved from: https://www.minrol.gov.pl/eng/Reports-andPublications/RURAL-DEVELOPMENT-PROGRAMME-for-2007-2013 [accessed by 201701-15].

[62] Ministry of Agriculture and Rural Development of the Slovak Republic (2007). Rural Development Programme of the Slovak Republic 2007-2013. Retrieved from: http://www.mpsr.sk/en/index.php?navID=1\&id=19,\%20Chapter\%203\%202\%20-

$\% 20$ Strategy\%20chosen [accessed by 2017-01-15]. 
[63] PRISMA (2009). Rural cultural heritage in Europe: From past to present. A Synthesis Report of Research. Compiled and edited by PRISMA, Athens 2009. Retrieved from: http://cultrural.prismanet.gr/themedia/File/CultruralReportForWeb.pdf.

[64] MMR ČR (2014). Integrovaný regionální operační program 2014-2020. Retrieved from: http://www.dotaceeu.cz/getmedia/207ddc91-a4de-42ff-9d98-27cdf9ef4c5a/PD-IROP20150604-schvalen-EK_2.pdf?ext=.pdf [accessed by 2017-01-19].

[65] Ministry of Agricuture (MoA)/ State Agricultural Intervention Fund (SAIF) (2016): data about implementation of Measure III.2.2 of the Rural Development Programme of the Czech Republic 2007-2013.

[66] OECD (2005). Culture and Local Development. Paris: OECD Publications.

[67] OECD (2014). Innovation and Modernising the Rural Economy. OECD Publishing. DOI: $10.1787 / 9789264205390$-en. 